\title{
A Study on the Value of the Integration of Music Education and Local Music Culture in Local Colleges and Universities Under the Background of New Liberal Arts Construction
}

\begin{abstract}
Bai yuqi
Music major of Music College of Guangxi Normal University

596062931@qq.com

Abstract

Culture is the soul and symbol of a nation and even a country. It is the historical deposit and foundation of a nation. We should not only inherit and carry forward the local culture, but also enhance the confidence of national culture, enhancing the soft power of culture. It is of great significance and research value to integrate local music culture into music education in local colleges and universities, which can not only enrich the content of music education, but also carry forward the characteristics of local music culture. The construction of new liberal arts provides a good opportunity and train of thought for the integration of Music Education and local music culture in local colleges and universities. Under the background of the construction of new liberal arts, music education in local colleges and universities integrates the local music culture, pays attention to the development and construction of professional music classes, and with its unique value, not only meets the requirements of the new era education, at the same time, it speeds up the process of cultural integration into the classroom and makes music education in colleges and universities more professional.
\end{abstract}

Keywords: background of new Liberal Arts Construction, Music Education in local colleges and universities, local music culture, Integration

\section{新文科建设背景下地方高校音乐教育与地方 音乐文化融合的价值研究}

\begin{abstract}
白玉琪
广西师范大学音乐学院音乐专业

596062931@qq.com

\section{摘要}

文化是一个民族乃至一个国家的灵魂与象征, 是一个民族的历史沉淀和根基, 我们不仅要继承和弘扬地方文化, 还要增强民族文化自信心, 提升文化软实力。将地方音乐文化荣融入到地方高校音乐教育中具有重要意义和研 究价值，这不仅仅能够丰富音乐教育的课程内容，还能弘扬当地音乐文化特色。新文科建设以其继承创新的精 神和交叉融合的特色, 为地方高校音乐教育与地方音乐文化融合提供了良好的契机与思路。在新文科建设背景 下，地方高校音乐教育融合地方音乐文化，注重开发建设专业性的音乐课堂，以其独特的价值，不仅适应新时 代教育的要求, 同时加快了文化融入课堂的进程, 让高校音乐教育更加的专业化。
\end{abstract}

关键词：新文科建设背景；地方高校音乐教育；地方音乐文化；融合 


\section{1. 研究背景}

《新文科建设宣言》于 2020 年 11 月发布, 对新 文科建设进行了全面部署, 并且成为了高等教育发展 的重要工作任务指标。宣言中指出, 新时代、新使命 的发展离不开文科教育的创新发展和建设, 由此看出 文科教育的创新与发展不仅有利于提升综合国力, 而 且还有利于各项科学发展以及提升国家文化软实力。 文科教育不仅能够增强文化自信, 而且可以为中华民 族伟大复兴中注入强大的精神动力。在新文科建设背 景下, 推进教育与文化融合发展。一方面, 通过对高 校教育与地方特色文化进行融合、强化与改革, 不仅 有助于培养出具有国际视野与国际竞争力的新时代 人才, 而且还保证了各学科专业之间交叉融合, 实现 教育上的推陈出新。另一方面, 《新文科建设宣言》 还提出, 在推进新文科建设和加快文科教育创新发展 的过程中，我们要坚持 “守正”与 “创新” 的精神。 在传承中创新是文科教育创新发展的必然要求, 既要 固本正源, 又要积极求变。优化改革教育本身的同时, 也需要继续传承并保护好我们国家优秀的文化宝藏。

本文主要对新文科建设背景下地方高校音乐教 育与地方音乐文化融合价值进行研究, 根据当地高校 现状和地方音乐文化现状展开分析, 研究其融合的价 值。其间得出三个重要路径方向：（1）坚定文化传 承理念; （2）教学重点应从传承性、文化性和地域 性三个方向进行研究; (3) 精于求新教学的模式。 在新文科建设的背景下, 我们要把握好 “守正”与 “创 新” 的正确关系, 明确 “固本” 和 “求新” 的正确理 念。取其精华, 去其糟粕, 科学的结合课程结构、教 学模式和教学方法等, 使得其能够革旧迎新和优化完 善。

\section{2. 新文科建设背景下地方高校音乐教育与地 方音乐文化融合的内涵}

音乐文化作为宝贵文化资源之一, 它也代表着音 乐这一产业的领头羊。音乐教育与音乐文化产业是音 乐体系中不可或缺的两个重要部分。两者看似相互分 离、独自发展、各司其职, 但同时也存在着千丝万缕 的关系。音乐教育与音乐文化产业之间, 两者相辅相 成、互相促进发展。求学者在音乐教育的学习过程中 丰富自己的内心世界，同时精神层面也得到了满足。 在此过程中提升自己对音乐美的意识和认知, 能够逐 渐培养乐感，并且充分的意识到音乐文化的重要性， 自发性地关注音乐文化产业的发展情况, 更好的对音 乐文化进行传承与保护。在音乐文化的传承与保护 上, 很大程度上保证了音乐文化产业的健康发展, 音 乐文化产业也因此拥有良好的前景与资源, 可以为音 乐教育培养人才的这块 “土地” 输送更多养分。在对 音乐教育进行改革与创新, 要求对音乐文化产业有清 晰且正确的认识。无论是在教育上进行改革还是创新 都与社会、人民密切相关, 加快音乐教育的发展不仅
关乎于教育本身，对于社会认可问题来说，也是占据 举足轻重的位置。是否能得到社会的认可也是至关重 要的必要条件之一。人们在音乐行业的需求和对音乐 产业文化的评价, 直接反映了对音乐教育专业人才培 养的要求, 反映了社会需要音乐专业培养怎样的人 才。

在新时代新背景下，我们以《新文科建设宣言》 为指导方向, “固本”与 “求变” , “守正”与 “创 新” 为优化方向, 将地方高校音乐教育与地方音乐文 化融合。不仅能够推进音乐教育健康快速发展的同时 与其他学科相互交叉, 还能与地方优秀音乐文化融 合, 加快了地方音乐文化产业成长进程。与此同时, 我们推进发展的同时，也对新文科建设背景下的地方 高校音乐教育与地方音乐文化的现状进行研究, 并分 析地方高校音乐教育与地方音乐文化融合的价值。

\section{3. 新文科建设背景下地方高校音乐教育与地 方音乐文化的现状}

\section{（1）地方高校现状}

中国高校的音乐教育旨在通过学习专业技能和 专业理论知识来培养优秀的音乐人才。其萌芽期可以 追溯到 20 世纪 50 年代, 但在发展的道路上出现过中 断现象, 直到 20 世纪 80 年代才逐渐恢复起来。因此, 与其他学科和专业的体系相比, 高校的音乐教育体系 完善得较晚,一些地方高校的音乐教育还存在一些实 质性的问题。例如：（1）在专业课程设置上，某些 课程的设置过于主观, 没有结合各方面因素并且从学 生的角度出发, 让学生在音乐学习中的许多不足之处 无法得到解决和改善, 学生毕业后就业时很难得到市 场的认可。（2）理论与实践之间存在一定的断链, 学生在课堂上主要是从音乐专业的书本上学习理论 知识, 缺乏将理论转化为实践的机会; 当学生毕业后 离开学校步入社会时, 由于缺乏实践经验, 导致需要 较长的时间来适应, 才能将所学的专业知识发挥好。

(3) 我国高校的音乐教育也一直以为社会输送更多 优秀的音乐教师为目标, 但同时也有不少音乐专业的 学生对地方音乐文化缺乏认知和了解, 甚至有些学生 对家乡的本土音乐文化较为陌生, 这样的现象在高等 院校中并不少见, 这是我们应该关注并且重视的。笔 者认为, 一个被社会和市场认可的优秀音乐教师, 不 仅是学生在课堂上畅游音乐知识海洋的引导者, 更重 要的是承担起传承中华优秀文化的责任, 带领学生认 识和接触地方优秀的音乐文化。

\section{（2）地方音乐文化现状}

随着当今社会的飞速发展，地方音乐文化产业对 地方文化和经济的发展有着深远的影响; 随着文化传 播和信息技术的广泛应用，在大力推动音乐文化产 业、科学文化产业等多种新兴产业发展同时，有利于 我们在推动地方各产业向更高层次发展。 ${ }^{[1]}$ 但是, 目 前我国地方音乐文化产业的发展道路上还存在着一 
些需要攻克的堡垒。一方面, 我国的音乐文化市场还 需要继续自我规范以及完善, 文化产业也需要更加成 熟有序的发展。我们应该注意的是, 当我们深入研究 如何优化音乐文化产业时, 我们的音乐文化产品市 场、音乐文化制作市场和音乐文化销售市场这三个部 分还有很大的上升空间。另一方面, 我国许多少数民 族的优秀文化瑰宝, 还需要更深层次的开发和利用。 在我国少数民族地区, 还有许多语言、音乐、舞蹈等 文化资源尚未进入公众视野, 并且为人们所熟知, 大 多都还处于 “犹抱琵琶半遮面” 的阶段。

《新文科宣言》对于新文科发展的必要性作出强 调, 文科教育的改革和发展离不开中华优秀传统文 化, 离不开国家文化软实力, 更离不开对高等教育的 振兴。着眼于我国当前背景下音乐教育与音乐文化现 状, 将优秀地方文化与地方高校音乐教育相融合, 是 我们打破学科专业的高墙, 推动音乐教育专业的改革 与创新, 是培养音乐文化产业、不断完善和健康发展 的必经之路。

\section{4. 新文科建设背景下地方高校音乐教育与地 方音乐文化融合的价值}

推动地方高校教育改革, 是我们发展新文科建设 工作中的重中之重。高等教育与之前其他教育阶段不 同, 高校教育需要的是对专业更加精细更加系统, 但 这种 “精细化” 和 “专业化” 的过程中难免会将 “高 塔” 垫高, 忽略地方文化这朵 “鲜花” 的芬芳, 使课 程理论内容单一化, 培养人才机制陈旧化。在地方高 校与地方音乐文化的融合过程中, 取其优秀的地方音 乐文化融入到地方音乐教育的课程中, 有利于丰富课 程内容得同时, 学生也能了解地方音乐文化, 甚至学 习一些比较有特色的地方音乐文化内容。习近平总书 记曾在 9 月 10 日的全国教育大会上指出, 要深化教 育体制改革, 调整优化高校区域布局、学科结构和专 业设置, 积极投身到创新驱动发展战略中去。 ${ }^{[2]}$ 将地 方高校音乐教育与地方音乐文化的融合, 不仅有利于 优化高校音乐教育的课程和教学结构, 更利于培养能 上 “高楼” 和培育 “鲜花” 的高素质人才。

地方高校音乐教育与地方音乐文化的融合可以 形成 “互利双赢” 局面。近年来, 音乐专业学生高涨 不下, 造成了一些地方高校音乐教育资源的短缺, 例 如琴房、演奏厅、排练室等硬件设施存在较大的供给 缺口。当地的音乐文化产业处于 “停滞” 的状态, 裹足不前。假设音乐专业的学生能够参与到当地地方 音乐产业的发展建设中来, 利用自己在专业中所学技 能为音乐文化产业贡献出自己得力量, 比如积极尝试 到当地的民间采风，收集各种特色的音乐文化资源、 撰写记录、调查并发表, 这既是对当地音乐文化的一 种保护, 也是对其的一种推广。当地的音乐文化产业 也可以为该院校音乐专业的硬件设施提供一些物质 帮助, 将特色音乐文化带入课堂, 形成该地方院校音 乐专业的特色。
最后，地方音乐文化产业的发展可以为地方高校 的音乐专业人才提供更多的就业机会, 而音乐专业的 学生也可以获得更多提高实践能力的机会。音乐文化 产业的发展离不开高校音乐教育培养的人才, 需要音 乐表演、音乐制作、音乐理论等多方面的音乐人才得 加入。它还需要符合行业和社会需求的高素质人才, 以促进行业的快速发展, 并同时得到社会和公众的认 可。我国坚持人才引领的发展战略, 党和国家始终重 视人才的培养和教育的发展, 只有坚持以教育为核 心，突出创新意识和实践能力，“固本” 的同时精于 “求新”, 才能培养出更多的创新人才和高素质人才 投身到行业中来。携手推动包括音乐文化在内的文化 产业发展, 提升国家文化软实力, 坚定文化自信, 为 中华民族的伟大复兴而奋斗。 ${ }^{[3]}$

\section{5. 新文科建设背景下地方高校音乐教育与地 方音乐文化融合的路径}

\section{（1）坚定文化传承理念}

地方音乐文化融入地方高校音乐教育时, 首先要 注意从新一代大学生的文化传承角度出发, 对当前高 校进行正确的引导和培养。地方高校作为地方音乐文 化传播的重要途径之一, 更是新时代背景下培养高素 质人才的摇篮。在培养学生正确文化观的过程中, 地 方高校要引导学生认识到文化传承与保护的重要性, 尝试在每学期或每学年开展 “地方音乐文化进校园” 的活动。以音乐节的形式, 将地方音乐文化中的戏剧、 山歌、舞蹈等节目通过活动带入学生的视野。这样不 仅可以激发学生对地方音乐文化的热爱, 还可以调动 他们学习的积极性。在进行集体班会或开展大学生政 治思想工作时, 可以以宣传中国优秀地方音乐文化为 渠道, 鼓励学生树立文化自信, 同时以坚定文化传承 理念为目标, 中国地方音乐文化和音乐文化产业的可 持续发展为方向, 保护和传承我们的优秀地方音乐文 化。只有首先树立正确的思想观念, 才能保证后续工 作的有效性和可持续性, 才能使地方音乐文化在内的 中国音乐文化持续富有生命力的发展下去。

\section{（2）着重把握教学特点}

在地方高校的音乐教育中, 理论知识和专业技能 的学习是必不可少的, 但在需要融入地方音乐文化的 背景下, 我们在教学方面应注意三大特点。

\section{\{1\} 传承性}

我们将地方音乐文化融入地方音乐文化的首要 目标, 是为了让地方音乐文化得到更完整和可持续的 继承和发展。这不仅需要学生长期的学习积累, 也需 要教师更加专业、系统的教学和培训, 这两者都离不 开教师和学生的共同努力。因此, 在这个过程中, 我 们不仅要理解文中所说的文化遗产的概念, 更要理解 遗产的必要性和目的。在教学之余, 教师还可以鼓励 学生结合自身情况, 对地方音乐文化进行更深层次的 研究, 并在这一方面学有所得学有所获, 甚至成为与 
之相关的专业人才。

\section{\{2\}文化性}

由于地方音乐文化的背后都有自己的文化底蕴, 所以我们在教学时, 学习地方音乐文化的语言、技能 等知识是非常必要的, 但值得注意的是, 学习方法不 仅要具备科学性, 还必须要有针对性, 不能过于按部 就班。在学习过程中, 也要避免用过于局限的视角去 分析和解读问题, 要把握正确的文化观和价值观。

\section{\{3\}地域性}

浓厚的地方色彩是地方音乐文化最鲜明的特征 之一，这可以成为我们区分各个地方音乐文化的 “指 南针”。我们在音乐课堂上, 可以将主要学习的地方 音乐文化与其他地方音乐文化进行对比, 让学生更直 观地体验两种完全不同的音乐形式, 感受两者不一样 的音乐课堂。 ${ }^{[4]}$ 从而可以直接引申出地方音乐文化背 后的审美内涵和人文价值, 并鼓励学生根据不同地方 的地理环境和风土人情等各种因素, 思考这些差异的 原因, 感受地方音乐文化的独特魅力。由此我们可以 发现, 在将地方音乐文化引入课堂时, 既要实现地方 高校音乐教育与地方音乐文化融合, 又要保持正确的 科学价值观和文化观。

\section{（3）精于求新教学模式}

在地方高校的音乐教育中, 不可避免会出现单一 的教学模式, 在专业理论课上大部分教师会采用多媒 体作为主要教学工具来辅助教学, 用以播放 PPT、图 片和音频, 讲授法为辅助。在专业技能课上, 大部分 以教师示范、学生模仿学习为主要的教学形式。这种 模式虽然取得了一定的成效, 但在新时代的新挑战 下, 缺陷也逐渐被放大, 音乐教育不仅能培养学生对 音乐这种艺术的审美修养, 也要激发学生对音乐艺术 创作和表演的自主性。在将地方音乐文化引入音乐教 育时, 由于地方音乐文化所具有的地域差异, 我们必 须对教学模式进行一定的优化和创新, 将地方音乐文 化引入其源头。'在教学中, 我们可以发挥地域优势, 采用带领学生实地考察学习等教育方法, 通过实地观 看当地歌舞, 获得最直观、最真实的感受。

另一方面, 我们还可以成立地方音乐文化工作 室, 由专业教师领头, 带领学生对地方音乐文化进行 深入研究或艺术实践, 不仅能让学生在获得更多知 识, 同时也可以为自己的专业实践获得更多机会, 除 此之外, 更重要的是可以更好地发扬和保护地方音乐 文化。因此, 随着教学模式的创新, 我们不仅可以提 高教学质量, 还可以为学生提供专业多元化的机会。

\section{6. 结论}

音乐教育作为大学教育中不可或缺的艺术学科, 不仅能让学生掌握理论知识和技能实践, 同时也沉淀
着浓厚的人文内涵。在新文科建设背景下地方高校 音乐教育与地方音乐文化融合, 对 “动脑” 和 “动手” 都有很高的要求, 同时也代表了高等教育中学生全面 发展的需求。着眼当下, 高校音乐教育正在全面大跨 步的向前发展, 我们在收获硕果累累的同时, 其存在 的意义与价值得到了社会和人民一定的认可, ${ }^{\left[{ }^{[5]}\right.}$ 也在 不断革旧迎新的优化和改革的步伐中, 逐渐形成较为 科学的教学体系, 这些都离不开国家对教育的支持和 人民对高等院校的肯定。但与此同时, 我们也迎来了 新的挑战, 随着社会和时代的不断进步与发展, 高等 院校的音乐教育也需要齐头并进、携手向前, 既要避 免 “单一化” “陈旧化” 局面的情况出现, 又要避免 固步自封的 “高塔” 䇯立。

在新文科建设的背景下, 我们要把握好 “守正” 与 “创新” 的正确关系, 明确 “固本” 与 “求新” 的 正确理念。要把地方高校的音乐教育与地方音乐文化 相互融合起来, 有选择的对地方音乐文化取其精华, 去其糟粕, 科学的结合课程结构、教学模式和教学方 法等, 使得其能够革旧迎新和优化完善。由此将培养 出的音乐专业高素质人才, 作为地方音乐文化产业发 展的强大动力, 使其快速发展不断壮大音乐领域的备 选人才。尤其是当地方音乐文化需要被新一代传承和 发扬的时候, 地方音乐教育也承担起作为前者的坚强 后盾与中流砥柱的责任, 并在这过程中实现自我突 破。这将会是一个 “双赢” 的结果, 也同样是我们面 对新时代新挑战时的迫切需要。

\section{REFERENCES}

[1] Zhang,X,M.Ma,Q,M.(2012) The Inheritance of Local Music in Local College Music Education. Big stage, 08:25 1-252.

[2] Zhang,Y. (2014) Practice and innovation of local music culture in music education of local colleges and universities. Journal of Hubei University of Science and Technology,09:160-161

[3] Chang,C. (2020) Research on the training mode of applied talents for music education major in colleges and universities. Music World, 08: 42.

[4] Sun,y. (2003) A study on the training mode of applied talents for music education major in colleges and universities. Journal of China Three Gorges University (Humanities and Social Sciences), 4: 77.

[5] Zhou Lin. ( 2019 )Exploration on the cultivation of humanistic quality in College music Education [J]. Contemporary Music, 7: 40. 